\title{
Students' Self-Organization and Problem Solving Competencies Formation in Explaining Water Resources Ecological Conditions and Bioecological Features of Azolla caroliniana
}

\author{
Akylbu Zulushova1, Dinara Emilbekova², Umida Isakova1, Zharkynai Shermatova1, \\ Roza Shaimkulova1, Zhypargul Abdullaeva ${ }^{*}$ (1)

\footnotetext{
${ }^{1}$ Department of Physical Geography and Applied Geodesy, Osh State University, Osh, Kyrgyzstan

${ }^{2}$ Department of Biology Teaching Methods, Osh State University, Osh, Kyrgyzstan

${ }^{3}$ Department of Natural Sciences, Medical Faculty, Osh State University, Osh, Kyrgyzstan

${ }^{4}$ Department of General Chemistry, Osh State University, Osh, Kyrgyzstan

${ }^{5}$ Department of Economic Geography and Tourism, Osh State University, Osh, Kyrgyzstan

${ }^{6}$ Department of Natural Sciences, Medical College, Osh State University, Osh, Kyrgyzstan

${ }^{7}$ Science and Research Department, Osh State University, Osh, Kyrgyzstan

Email: *jypar.science@oshsu.kg
} Nasyr Manasov ${ }^{3}$, Aishakan Suiunbekova ${ }^{4}$, Dinara Keneshbaeva ${ }^{5}$, Zhazgul Abdyrakhmanova ${ }^{6}$,

How to cite this paper: Zulushova, A., Emilbekova, D., Isakova, U., Shermatova, Z., Manasov, N., Suiunbekova, A., Keneshbaeva, D., Abdyrakhmanova, Z., Shaimkulova, R., \& Abdullaeva, Z. (2021). Students' Self-Organization and Problem Solving Competencies Formation in Explaining Water Resources Ecological Conditions and Bioecological Features of Azolla caroliniana. Creative Education, 12, 1848-1857.

https://doi.org/10.4236/ce.2021.128140

Received: July 7, 2021

Accepted: August 8, 2021

Published: August 11, 2021

Copyright $\odot 2021$ by author(s) and Scientific Research Publishing Inc. This work is licensed under the Creative Commons Attribution International License (CC BY 4.0).

http://creativecommons.org/licenses/by/4.0/

\begin{abstract}
Self-organization and problem solving competencies are important in formation of students' knowledge, skills, attitudes and responsibility. In this article, authors explain formation of self-organization and problem solving competencies in students during teaching water resources ecological conditions. Enhancement of the ecological situation is the result not only of general crisis in the region economy, associated with low investment activity and the emergence of psychological disciplines, but also due to a large number of economic structures. Research goals and objectives in this study include bio-ecological features, the distribution of plant Azolla in the southern Kyrgyzstan and its use as a valuable green fertilizer, protein and vitamin supplement for various farm animals. Study of Azolla caroliniana and its influence on the water conditions in southern Kyrgyzstan can be concluded with year-round introduction in aquariums, trenches, shallow water, valuable plant biomass can be obtained, the use of which can solve such problems as increasing soil fertility, enriching feed with nutrients in branches of livestock, poultry, fish farming and wastewater treatment.
\end{abstract}




\section{Keywords}

Competence, Self-Organization, Problem Solving, Water Resources, Ecology, Monitoring, Anthropogenic Factor, Reclamation, Melioration, Azolla caroliniana, Bioecological Features

\section{Introduction}

The learning process focuses on students' individual self-awareness, motivation to learn, learning goals, strategies and cooperation with other students (Letina, 2020). Problem solving competency is high dimensional ability among humans' cognitive functions that are important and includes numerous other competencies (Yoon et al., 2020). Students self-organization skills can be formed by following stages: 1) indicative target; 2) theoretical diagnostic; 3) design constructing; 4) technological; 5) evaluative reflective; 6) corrective (Kotova \& Shakhmatova, 2007). Students' self-organization skills referred to leadership skills consisting of behavioral and cognitive approaches designed to positively influence personal productiveness (Goldsby et al., 2021). Competency is related to job performance and approach combining several points such as: 1) knowledge collection, skills, attitudes; 2) job tasks identification; 3) qualities of superior performers that can be measured reliably (Klein \& Richey, 2005). Ability to solve a complex hydrological problem typically includes: 1) definition, identification and analysis of problem; 2) identification or development of possible solutions and selecting the optimal way; and 3) solution implementation (Pathirana et al., 2012).

Initially, teachers start with difficulties about water resources to activate students' thinking for problem solving: in recent years, water consumption for industry needs fall, as a significant part of water, which is prepared for drinking needs is used for technical and other purposes, and is also decreasing due to leaks from domestic water supply and sewerage systems, street water treatment plants. Despite large expenditures, it is still not possible to provide the urban population with water of guaranteed quality in terms of physicochemical and microbiological parameters, due to the structural imperfection of water using structures, errors in the operation of the filter stations, frequent accidents at physically obsolete sections of distribution networks, the absence or malfunction of stop valves, design flaws of the water columns. Kyrgyzstan faces many ecological and environmental problems such as land degradation, pollution of rivers and glacial degradation (Hao et al., 2019).

After problem setting, the upcoming work is planned and discussed after which students need to know about topic to solve the problem (Chetvertak, 2012).

Management of natural resources based on the development discourse maintained by community-based approaches generally equitable, sustainable, and le- 
gitimized strategies (Dörre, 2015). Understanding complexity in environmental management requires strong decisions to minimize losses of species, necessary for responsible management of Earth's ecosystems and the biodiversity (Hooper et al., 2005).

Currently, the light industry in Kyrgyzstan is developing at a high level. Because goods made in Kyrgyzstan are sold on world markets. One of the main factors used in light industry is water resources. A significant part of water, which is prepared for drinking needs, is used for technical purposes and is also lost due to leaks from domestic water supply and sewerage systems, street plants water treatment.

On the city territory, an intensive selection of natural (surface and ground) waters is carried out. The regulatory framework does not provide incentives to save water and improve methods of wastewater treatment. The city consumes about $15,918,000 \mathrm{~m}^{3}$ water in a day. The technical productivity of city water supply sources is $228,000 \mathrm{~m}^{3} /$ day. Including water uses: Ozgur is $180,000 \mathrm{~m}^{3} /$ day, Mady is $23,000 \mathrm{~m}^{3} /$ day, pumping station No. 5 is $18,000 \mathrm{~m}^{3} /$ day, well No. 7 is $7000 \mathrm{~m}^{3} /$ day. However, the technological productivity of water use is $25 \%-30 \%$ lower. During the period of production stability, the industry consumed up to $60,000 \mathrm{~m}^{3} /$ day.

Purpose of this study is to activate students' self-organization and problem solving competencies by following components:

1) Why teach? (target component);

2) What to teach? (content component);

3) How to teach? (Procedural component: methods, forms, means);

4) Motivational component;

5) Evaluation component.

Practical importance in this work contains several new scientific results and provisions that have internal unity, which indicates the personal contribution of the author to biological science. In general, the work is of great scientific and practical importance and plays an important role in biogeocenosis.

Teaching goals were set as follows:

- Educational goal: explain the water properties, importance in life and how to treat water;

- Developmental goal: awakening and formation of ecological consciousness in students by teaching to use clean water sparingly;

- Upbringing goal: students will learn to use water efficiently, keep it clean and protect it;

- Understand that water is the source of life, cherish and value water.

Type of lesson: repetitive, supplementary, concluding lesson.

Bioecological features of Azolla caroliniana research attracting scientist attention. The ability of Azolla caroliniana to remove heavy metals ( $\mathrm{Hg}$ (II), $\mathrm{Cr}$ (III), $\mathrm{Cr}(\mathrm{VI})$ ) from municipal wastewater has been reported (Bennicelli et al., 2004). The study of rare species in need of protection is currently one of the priority 
tasks of botanical science in connection with the general trend of identifying and preserving biological diversity. Preservation of the Kyrgyzstan flora is currently an ecological problem in the republic as a result of human economic activity and the impact of various environmental factors, many plant species (Borchardt et al., 2011) have become rare and are on the verge of extinction. Among rare and endangered plants in Kyrgyzstan, Azolla caroliniana Willd is of particular interest to science (Banach et al., 2020; Azab \& Soror, 2020). Azolla caroliniana is a relict plant of the tertiary period. The stomata of floating Azolla coexist in a unique symbiosis with $\mathrm{N}_{2}$-fixing cyanobacteria (Anabaena azollae), which are symbiotes that absorb nitrogen from the atmosphere. It is of great importance in South and East Asia as a biofertilizer and is valued for its nitrogen-fixing ability, and beneficial for crops such as rice, as well as for poultry and animal husbandry. For these purposes, it is relevant and necessary to study the morphological and structural features, methods of reproduction and the method of application of Azolla caroliniana (Figure 1).

\section{Research Methods and Materials}

Research methods in this work are based on the collection, observation, analysis, quantitative calculation and monitoring of obtained results. Botanical work was carried out using generally accepted floristic and geobotanical methods. To study the plant anatomical structure, we use the microscope and tools including aquariums, desiccators, water pools, microscope, electronic scales, thermometer, water thermometer, etc. Additionally, the following research methods used: scientific and theoretical analysis; research forms: seminars, discussions; research materials: audio, video materials, multimedia technologies, computer software.

Theoretical research methods (Figure 2) aimed at creating generalization, establishment and formulation of laws, phenomena and processes that include:

1) The systemic and structural approach, consisting of facts that met research considered as a holistic system of interconnected elements. This approach assumes certain goals, selection of content, methods and means of teaching a lesson, assessment the effectiveness of the lesson;

2) A typological approach is the grouping of study objects and phenomena; an essential feature of each group highlighted. It finds application in the study of all problems in methodological science;
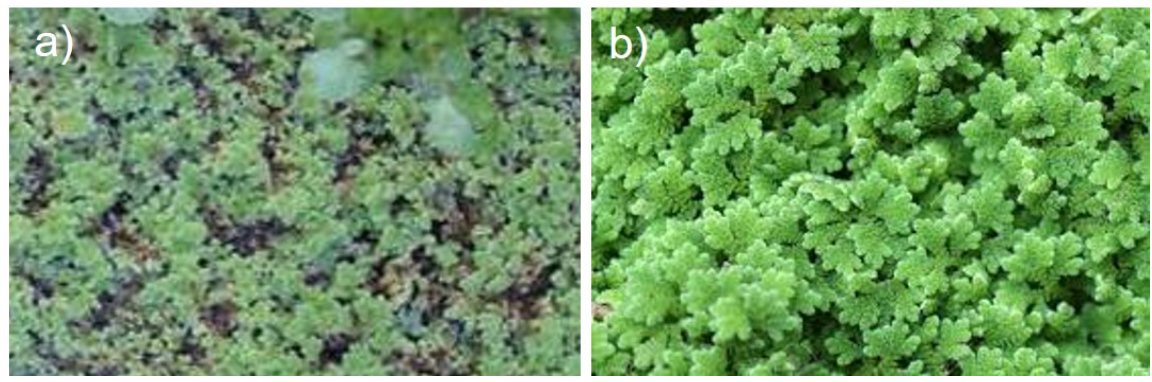

Figure 1. (a) Pond grown Azolla caroliniana; (b) Enlarged image of Azolla caroliniana. 


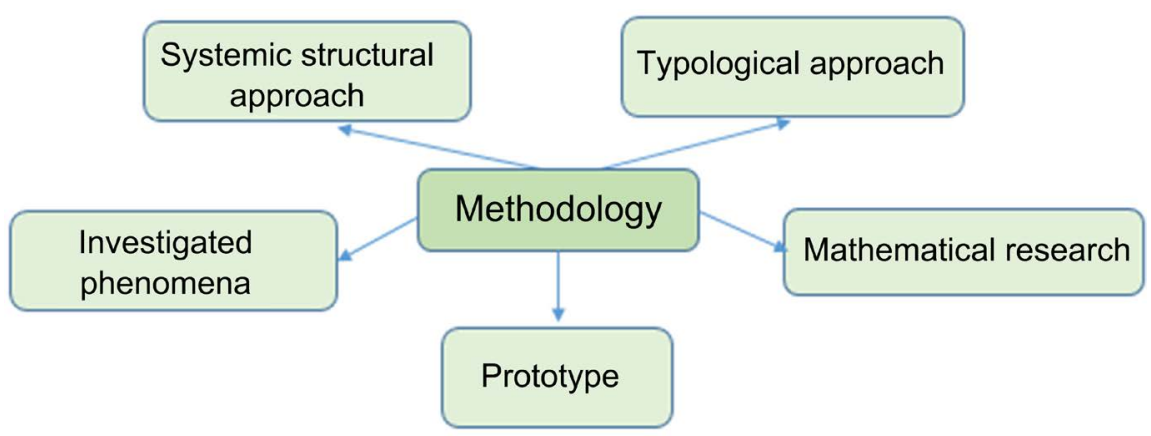

Figure 2. Research methodology used in the development of students self-organization and problem solving skills.

3) Research method including all investigated phenomena considered development and change over time. This method helps to attract historical and methodological research in the study of problems in teaching modern geography;

4) The modeling method consists of facts that in a simple and affordable form, the object becomes a model of more complex objects called a prototype. An example is a globe model;

5) Mathematical research methods are not limited to conducting calculations. Their main function is to identify and explain complex relationships and patterns of pedagogical phenomena.

\section{Results and Discussions}

\subsection{Water Resources Ecological Condition}

According to the city sanitary and epidemiological station, in 1999, the microbiological indicators of water in distribution networks, 18.9 percent of the number of samples examined, did not meet requirements of the Government Standard and Sanitary Norms and Regulations.

In 2000, this indicator worsened 1.9 times and amounted to 35.7 percent. Poor water quality in terms of microbiological indicators is consistent with the incidence of viral hepatitis " $A$ " in the city population, which is causally related to the use of poor-quality drinking water. The incidence of viral hepatitis in the city population in 1999 in absolute terms was 1159 cases, of which hepatitis A was 896 cases or 77.3 percent, and in $2000-2980,2615$ or 87.7 percent, respectively. Thus, there is a direct relationship: the worse the quality of tap water, the higher the incidence of viral hepatitis " $\mathrm{A}$ " in population.

\subsection{River Ecological Conditions}

Many problems have accumulated for the protection and rational use of the city surface waters. The Ak-Buura river and the main canals of the city are polluted and clogged. The Ak-Buura river was the first and main city-forming factor for Osh in historical terms and is still one of the city's attractions. Rather, it could have been if a set of measures for its improvement, landscaping and health improvement had been carried out. 
The water of the river at its sources meets all environmental parameters, but within the city limits, the deterioration of the quality of natural water in terms of the organic component is already clearly noticeable (the content of dissolved oxygen decreases, the indicators of oxidizability of the biochemical oxygen demand increase, ammonia appears as a sign of fresh fecal pollution, the processes of mineralization are a weak group of ammonia). This is a progress consequence of solid and liquid waste from industrial enterprises, recreation areas and residential areas into the water. In the middle of the city, these negative processes continue to grow and below the wastewater discharge from the city sewage system, the water acquires properties that make it unsuitable for household, drinking and recreational purposes without appropriate preparation. This violates the fundamental principle of international law, which states that countries located along the river should not cause tangible damage to countries located downstream. The design and laying out of the boundaries of the water protection zones of the river has begun, but not completed, work is slowly being carried out to regulate the channel and green banks. The conclusions can be made as following:

- Water resources are a strategic, vital resources;

- Surface and ground waters are subject to intense and chemical pollution;

- No effective measures implemented to conserve and redistribute water resources;

- Business entities do not introduce waste-free technologies and measures for the recycling and reuse of natural waters.

To obtain the expected results, it is necessary to hold competitions on the territory of the city and the adjacent territory of city for landscaping, wastewater treatment and waste collection from containers, as well as along the banks of the Ak-Buura river.

\subsection{Water Resources in Ecosystem}

The global ecological situation, despite some success in the field of environmental protection, continues to deteriorate. As noted at the special session of the UN General Assembly (June 1997), the planet is threatened by the onset of an environmental crisis.

One of the most important global problems of serious concern all humanity is the increasing human impact on nature, which threatens to disrupt the dynamic balance in nature. The rapid development of the scientific and technological revolution, the rapid growth of industry, motor transport, growth. the number and urbanization of the population, industrialization and chemical enrichment of agricultural production, all these factors inevitably lead to an increase in the exploitation of natural resources, have an impact on the nature surrounding a person are a flora and fauna, the state of the subsoil, soil, air and water basins.

Water occupies a special, dominant place among the natural resources on the Earth.

Water resources use in sustainable way coupled with the land planning strate- 
gies ensuring suitable groundwater resources for multiple purposes (drinking water supply, irrigation, agriculture and livestock products (Pacheco, 2020). Freshwater is irreplaceable; metals, oil, gas have alternatives but not freshwater. The main condition for life on Earth is not just water, but clean, fresh drinking water, without which a person cannot withstand more than $3-4$ days. In our time, freshwater has become one of the scarcest natural resources. Freshwater is the national wealth of Kyrgyzstan. The area of the rivers of Kyrgyzstan is 199.1 thousand $\mathrm{km}^{2}$ the river runoff formed within the republic is $51.8 \mathrm{~km}^{3}$. Kyrgyzstan is the only country from all the countries of the former USSR that does not take a drop of water from the neighboring republics.

Therefore, the protection of water supply sources from natural pollution introduced with domestic and industrial wastewater, as well as the development and application of the most advanced methods and schemes for the preparation of these waters for communal and technical purposes is a task of exceptional importance.

Changes in the country environment under the influence of anthropogenic factors can occur very quickly, covering large areas. Therefore, the general idea of the current ecological situation is closely related to the degree of anthropogenic pressure on the environment (Popova et al., 2019; Cozzi et al., 2020). At this time, the territory of its suburbs can be attributed to Osh city and territories with a tense ecological situation. The tense ecological situation is characterized by a high anthropogenic load. There are conditions for the combined, complex action on the human body of chemical, physical and biological environmental factors. The compensatory capabilities of the environment are largely depleted. Corrective human action is necessary through the development and implementation of action programs for environmental protection.

\subsection{Environmental Safety Concept}

That is why, in 2007, the Osh Government Administration, together with the Osh Regional Department of Environmental Protection, developed the "Concept for ensuring the environmental safety in Osh city for the period until 2017". In this concept, a large role assigned to the water resources in Osh and suburbs. "Hot spots" in Osh city have been identified for water bodies, one of which is transboundary pollution of the river. Ak-Buura and the canals departing from it with organized wastewater from the city sewerage system and unorganized wastewater and solid household waste from the residential sector.

The Ak-Buura river is supplied by glaciers and snow. It originates from the northern slope of the Alai ridge, in the sources it called as Kichi-Alai. According to the water regime, it belongs to the rivers of the Tien Shan type with floods in the warm season April length $148 \mathrm{~km}$, catchment area annual flow is 674.9 million $\mathrm{m}^{3}$, discharge is $21.4 \mathrm{~m}^{3} / \mathrm{sec}$.

Water supply to the population in Osh city and its suburbs is carried out mostly by the water of the Ak-Buura river. The water from the Ak-Buura river is 
used for irrigation of lands; for this purpose, the Papan reservoir with a volume of 260 million $/ \mathrm{m}^{3}$ was built in the middle reaches of the river. The Ak-Buura river condition is one of important indicators determining the ecological situation in Osh city, its suburbs and residential border of Uzbekistan using this water. To determine the indicators of water quality, it is necessary to analyze it. The analysis reveals the nature of water pollution, the degree of its epidemiological and toxicological hazard.

\subsection{Students Assumptions}

Analysis of many stock materials led students to the following conclusions:

1) The waters of the Ak-Buura river are subject to intense chemical and biological pollution;

2) The main types of pollution are industrial and municipal wastewater, runoff from fields subjected to agrochemical treatment, storm and melt runoff from the territory of settlements, solid domestic waste, i.e. the main pollutant of the Ak-Buura river is anthropogenic factors;

3) The potential danger of water epidemic of intestinal infections through water remains;

4) The waters of the Ak-Buura river need strict state measures for their rational use and protection.

Based on all of the above, students offer the following recommendations for improving the Ak-Buura river conditions:

1) To monitor the waters of the Ak-Buura river;

2) Determine and fix the boundaries of the water protection zones of the Ak-Buura river;

3) Limit and stop economic activity in the water protection zones of the Ak-Buura river;

4) Ensure wastewater treatment at urban sewerage facilities to the extent that meets the regulatory requirements when discharged into the Ak-Buura river;

5) Osh regional department of environmental protection, together with environmental NGOs, students, schoolchildren, to carry out raids along the river Ak-Buura to identify sources of pollution, to carry out cleaning activities and green the banks of the Ak-Buura river.

After analysis of above materials, students received the following review questions and tasks for independent working:

1) What are the goals of general secondary education at school?

2) What is the content of education?

3) What are the main directions of restructuring education today?

4) Give examples of integration and differentiation of scientific geographic disciplines.

5) Prove that geography is necessary part of the general average education.

6) What are the main problems facing the methodology of teaching geography in connection with the development of the content in the school curriculum? 
What are the main ideas inherent in the content of school geography curricula?

\section{Conclusion}

Research results obtained in this study: formation of students' problem solving, self-organization and ecological culture. Students' self-organization skills can be formed by several stages: indicative target, theoretical diagnostic, design constructing, technological, evaluative, reflective and corrective.

At the end of class students' came to the following conclusions:

- Keep basics in human life safety;

- It is necessary to solve global environmental problems, issues of climate change and overcoming their consequences, in rational nature management and energy efficiency;

- Planning lessons subject, with topics and sections specifics according to the program and curriculum;

- Search for implementation ways in professional self-education and personal growth, designing further educational trajectory with professional career;

- Realization of basics in modern natural and fundamental sciences for the implementation and intersubjective connections in biology, geography, chemistry and physics;

- Organic world development patterns;

- Place of inorganic and organic systems in the Earth evolution, the unity of the lithosphere, hydrosphere and atmosphere;

- Principles and methods in rational energy and resource use.

\section{Conflicts of Interest}

The authors declare no conflicts of interest regarding the publication of this paper.

\section{References}

Azab, E., \& Soror, A. S. (2020). Physiological Behavior of the Aquatic Plant Azolla sp. in Response to Organic and Inorganic Fertilizers. Plants (Basel, Switzerland), 9, 924. https://doi.org/10.3390/plants9070924

Banach, A. M., Kuźniar, A., Grządziel, J., \& Wolińska, A. (2020). Azolla filiculoides L. as a Source of Metal-Tolerant Microorganisms. PLoS ONE, 15, e0232699. https://doi.org/10.1371/journal.pone.0232699

Bennicelli, R., Stepniewska, Z., Banach, A., Szajnocha, K., \& Ostrowski, J. (2004). The Ability of Azolla caroliniana to Remove Heavy Metals (Hg(II), Cr(III), Cr(VI)) from Municipal Waste Water. Chemosphere, 55, 141-146. https://doi.org/10.1016/j.chemosphere.2003.11.015

Borchardt, P., Schickhoff, U., Scheitweiler, S., \& Kulikov, M. (2011). Mountain Pastures and Grasslands in the SW Tien Shan, Kyrgyzstan-Floristic Patterns, Environmental Gradients, Phytogeography, and Grazing Impact. Journal of Mountain Science, 8, 363-373. https://doi.org/10.1007/s11629-011-2121-8

Chetvertak, S. V. (2012). Learning Activity of Schoolchildren: From the Practice of Moti- 
vation. Municipal Formation: Innovation and Experiment, No. 1, 13-16.

Cozzi, S., Cabrini, M., Kralj, M., De Vittor, C., Celio, M., \& Giani, M. (2020). Climatic and Anthropogenic Impacts on Environmental Conditions and Phytoplankton Community in the Gulf of Trieste (Northern Adriatic Sea). Water, 12, 2652. https://doi.org/10.3390/w12092652

Dörre, A. (2015). Promises and Realities of Community-Based Pasture Management Approaches: Observations from Kyrgyzstan. Pastoralism, 5, 15. https://doi.org/10.1186/s13570-015-0035-8

Goldsby, M. G., Goldsby, E. A., Neck, C. B., Neck, C. P., \& Mathews, R. (2021). SelfLeadership: A Four Decade Review of the Literature and Trainings. Administrative Sciences, 11, 25. https://doi.org/10.3390/admsci11010025

Hao, Y., Yang, D., Yin, J., Chen, X., Bao, A., Wu, M., \& Zhang, X. (2019). The Effects of Ecological Policy of Kyrgyzstan Based on Data Envelope Analysis. Sustainability, 11, 1922. https://doi.org/10.3390/su11071922

Hooper, D. U., Chapin, F. S. III, Ewel, J. J., Hector, A., Inchausti, P., Lavorel, S., Lawton, J. H., Lodge, D. M., Loreau, M., Naeem, S., Schmid, B., Setälä, H., Symstad, A. J., Vandermeer, J., \& Wardle, D. A. (2005). Effects of Biodiversity on Ecosystem Functioning: A Consensus of Current Knowledge. Ecological Monographs, 75, 3-35. https://doi.org/10.1890/04-0922

Klein, J. D., \& Richey, R. C. (2005). Improving Individual and Organizational Performance: The Case for International Standards. Performance Improvement, 44, 9-14. https://doi.org/10.1002/pfi.4140441004

Kotova, S. S., \& Shakhmatova, O. N. (2007). Psychological Features of Self-Organization of Educational Activities of Students. Research in Education, No. 4, 91-98.

Letina, A. (2020). Development of Students' Learning to Learn Competence in Primary Science. Education Sciences, 10, 325. https://doi.org/10.3390/educsci10110325

Pacheco, F. A. L. (2020). Sustainable Use of Soils and Water: The Role of Environmental Land Use Conflicts. Sustainability, 12, 1163. https://doi.org/10.3390/su12031163

Pathirana, A., Koster, J.-H., de Jong, E., \& Uhlenbrook, S. (2012). On Teaching Styles of Water Educators and the Impact of Didactic Training. Hydrology and Earth System Sciences, 16, 3677-3688. https://doi.org/10.5194/hess-16-3677-2012

Popova, A., Popova, V., Dorofeeva, V., \& Sorokopudova, O. (2019). Anthropogenic Environmental Pressure Influence on Oak Forest Biodiversity and Quercus Robur Mithosis Pathologies. IOP Conference Series: Earth and Environmental Science, 226, Article ID: 012022. https://doi.org/10.1088/1755-1315/226/1/012022

Yoon, J., Hur, E. J., \& Kim, M. (2020). An Analysis of the Factors on the Problem-Solving Competencies of Engineering Employees in Korea. Sustainability, 12, 1677.

https://doi.org/10.3390/su12041677 